\title{
Simultaneous detection of intracellular nitric oxide and peroxynitrite by surface-enhanced Raman scattering nanosensor with dual reactivity
}

Hua-Ying Chen a , Essy Kouadio Fodjo a,b, Lei Jiang a , Shuai Chang a , Jia-Bin Li a , De-Sheng Zhan

$$
{ }^{\text {a }} \text {, Hai-Xin Gu }{ }^{\text {c, Da-Wei Li }}{ }^{\text {a,* }}
$$

${ }^{\text {a }}$ Key Laboratory for Advanced Materials, Joint International Laboratory for Precision Chemistry \&School of Chemistry and Molecular Engineering, East China University of Science and Technology, Shanghai 200237, P. R. China

${ }^{\mathrm{b}}$ Laboratory of Physical Chemistry, Felix Houphouet Boigny University, Abidjan 00225, Cote d'Ivoire

${ }^{c}$ Shanghai Fire Research Institute of Ministry of MEM, Shanghai 200438, P. R. China

* Corresponding Author. E-mail: daweili@ecust.edu.cn (D.-W. Li) 


\section{Cytotoxicity of AuNP/DAPBAP nanosensor}

The macrophage cells were seeded in a 96-well plate with a $10^{5}$ cells/well density in culture medium $(100 \mu \mathrm{L})$ and were cultured in a $\mathrm{CO}_{2}$ incubator at $37^{\circ} \mathrm{C}$ for 24 hours. Then $10 \mu \mathrm{L}$ of nanosensor was respectively added into experimental wells and continued to culture for different time $(2 \mathrm{~h}, 4 \mathrm{~h}, 12 \mathrm{~h}, 18 \mathrm{~h}$, and $24 \mathrm{~h})$. The control experiment was the absence of nanosensor in the wells. After the old culture medium in the plate was changed by new culture medium, $10 \mu \mathrm{L}$ of CCK- 8 solution was added to experimental wells and incubated for $30 \mathrm{~min}$. Finally, the plate was measured the absorbance at $450 \mathrm{~nm}$ by using a microplate reader.

\section{Density Functional Theory (DFT) calculations related with the nanosensor}

In order to adequately understand the SERS variation of AuNP/DAPBAP nanosensor, the Raman spectra of the corresponding reaction compound $\boldsymbol{b}$ and $\boldsymbol{c}$ in the Figure 1 were calculated by DFT/B3LYP method with 6-311G++ (d, p) basis set. ${ }^{1}$ The polarizable continuum model (IEF-PCM) was applied to optimize geometry and eliminate the effect of aqueous circumstance effect. ${ }^{2}$ 


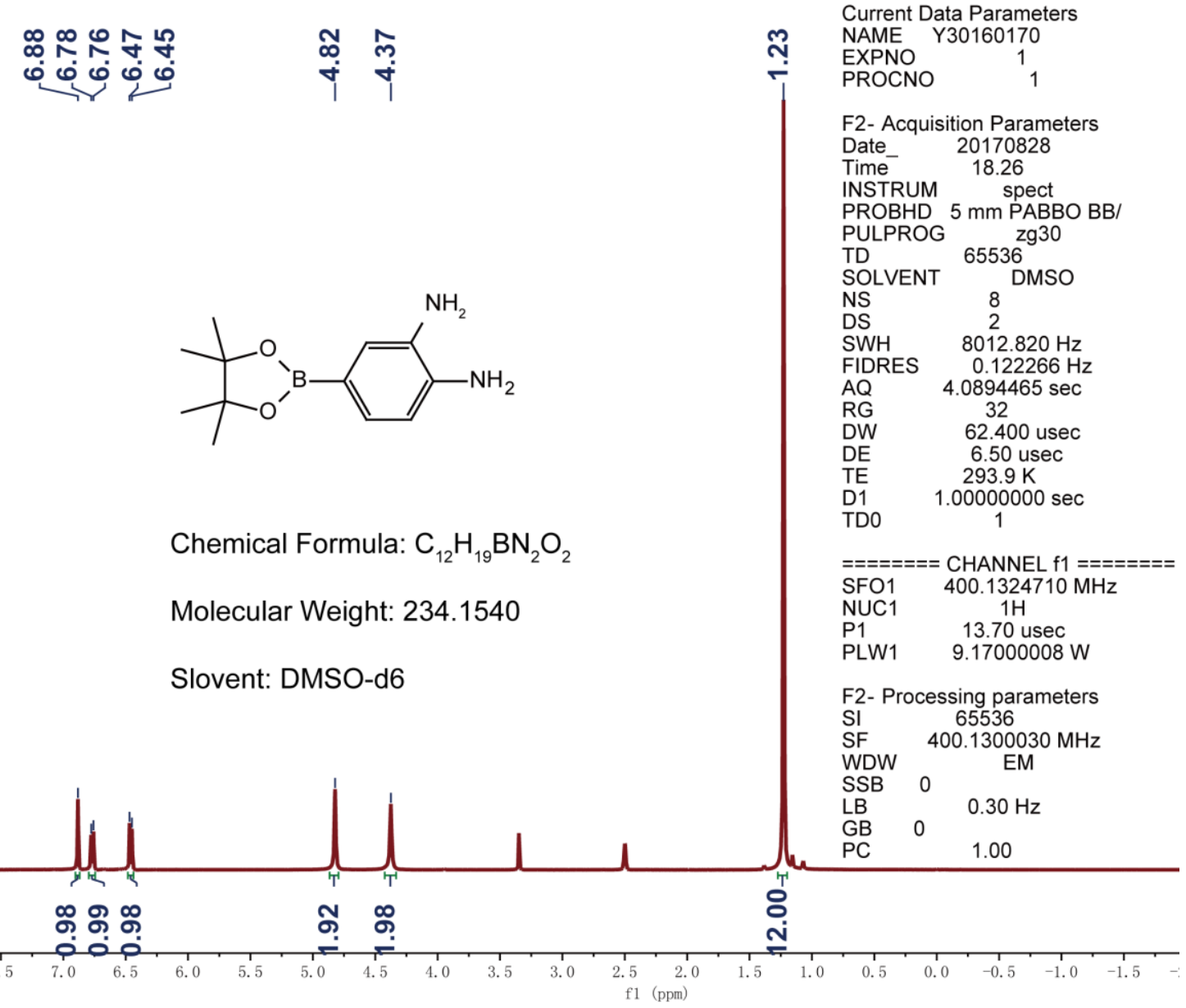

Figure S1. ${ }^{1} \mathrm{H}-\mathrm{NMR}$ spectrum of the synthesized DAPBAP molecules in DMSO-d6.

${ }^{1} \mathrm{H}-\mathrm{NMR}(400 \mathrm{MHz}, \mathrm{DMSO}) \delta 6.88(\mathrm{~s}, 1 \mathrm{H}), 6.77(\mathrm{~d}, \mathrm{~J}=7.6 \mathrm{~Hz}, 1 \mathrm{H}), 6.46(\mathrm{~d}, \mathrm{~J}=7.6$

$\mathrm{Hz}, 1 \mathrm{H}), 4.82(\mathrm{~s}, 2 \mathrm{H}), 4.37(\mathrm{~s}, 2 \mathrm{H}), 1.23(\mathrm{~s}, 12 \mathrm{H})$. 

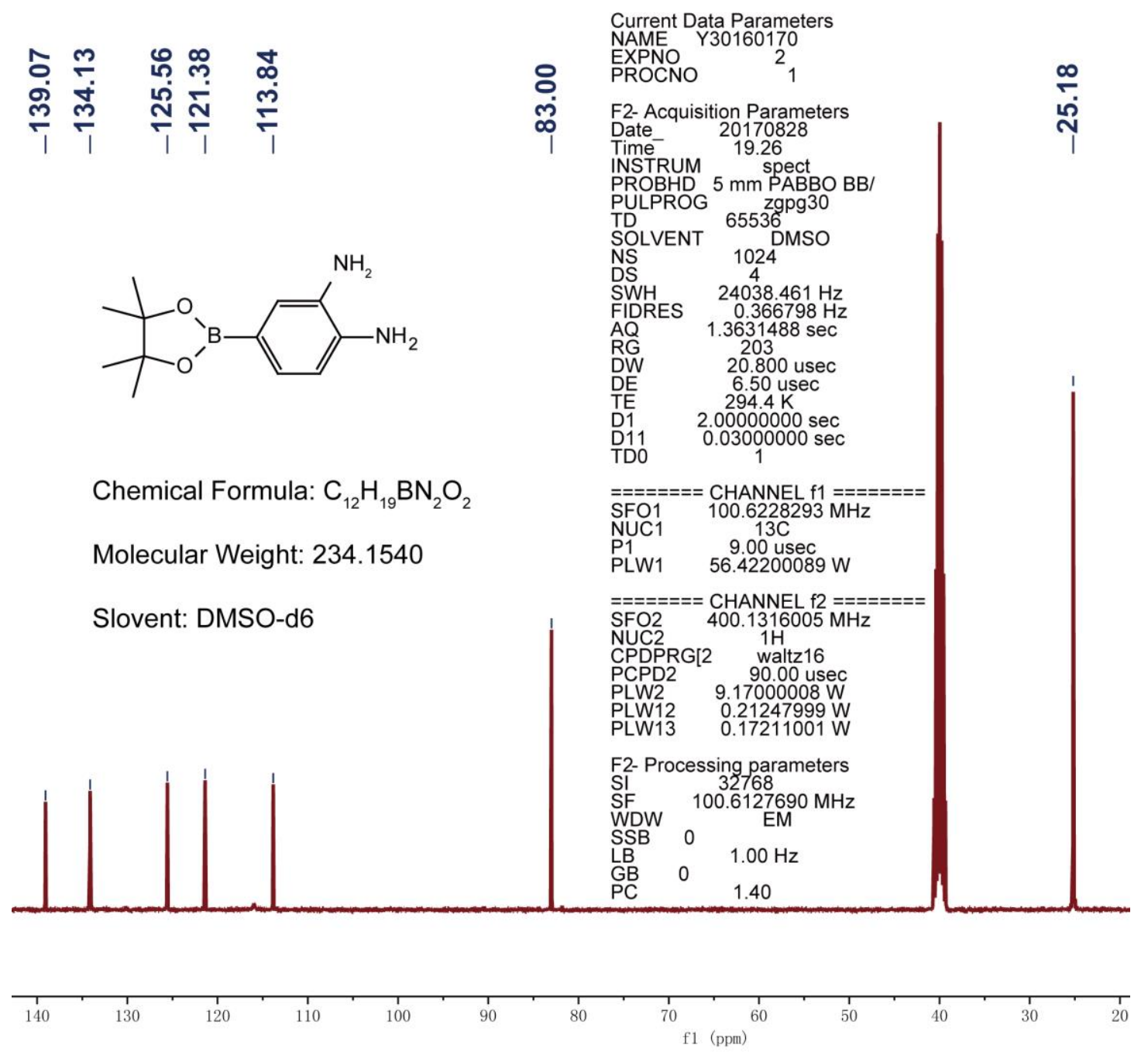

Figure S2. ${ }^{13} \mathrm{C}-\mathrm{NMR}$ spectrum of the synthesized DAPBAP molecules in DMSO-d6.

${ }^{13} \mathrm{C}-\mathrm{NMR}(101 \mathrm{MHz}, \mathrm{DMSO}) \delta$ 139.07, 134.13, 125.56, 121.38, 113.84, 83.00, 25.18. 

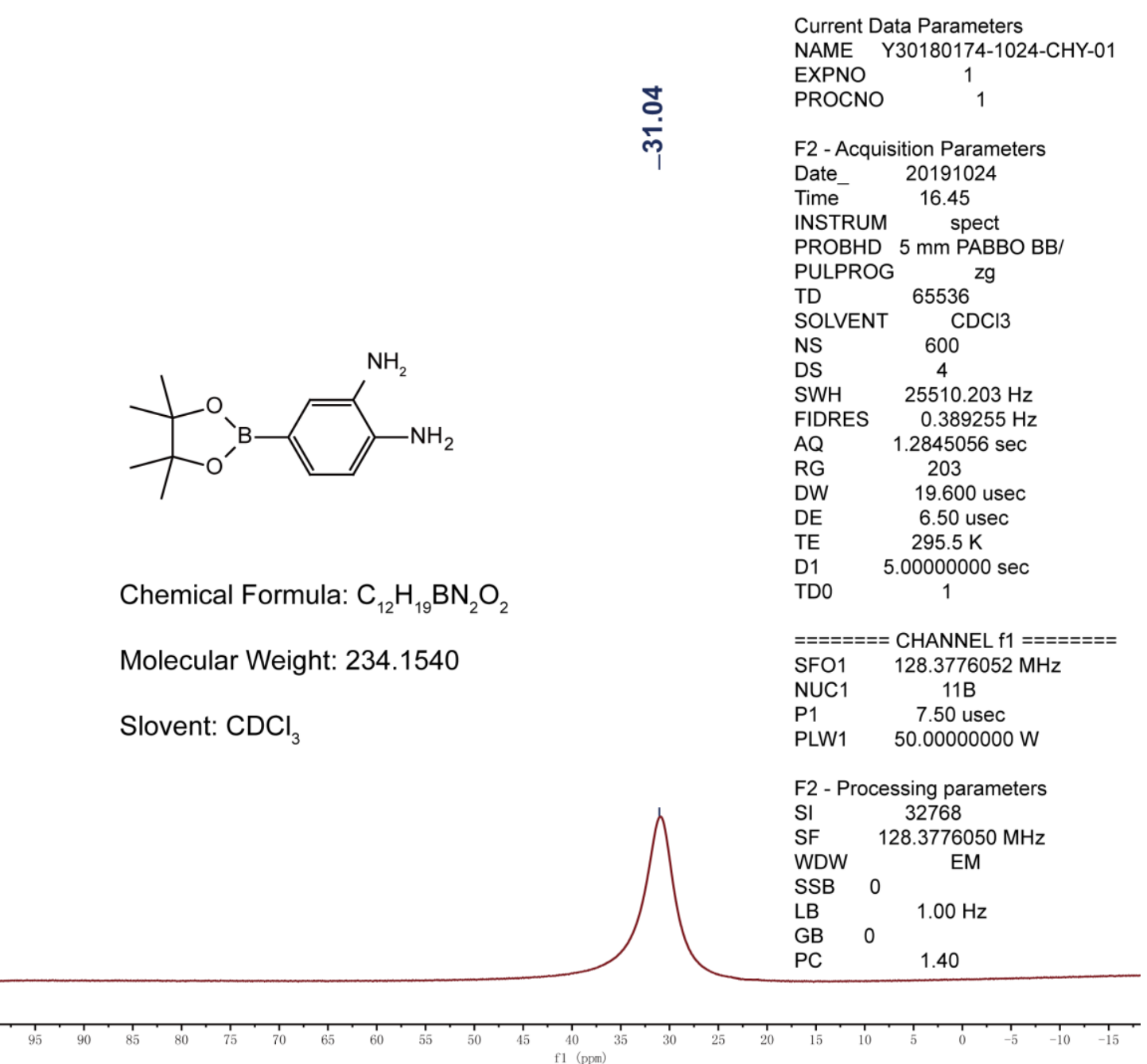

Figure S3. ${ }^{11} \mathrm{~B}-\mathrm{NMR}$ spectrum of the synthesized DAPBAP molecules in $\mathrm{CDCl}_{3}$. 


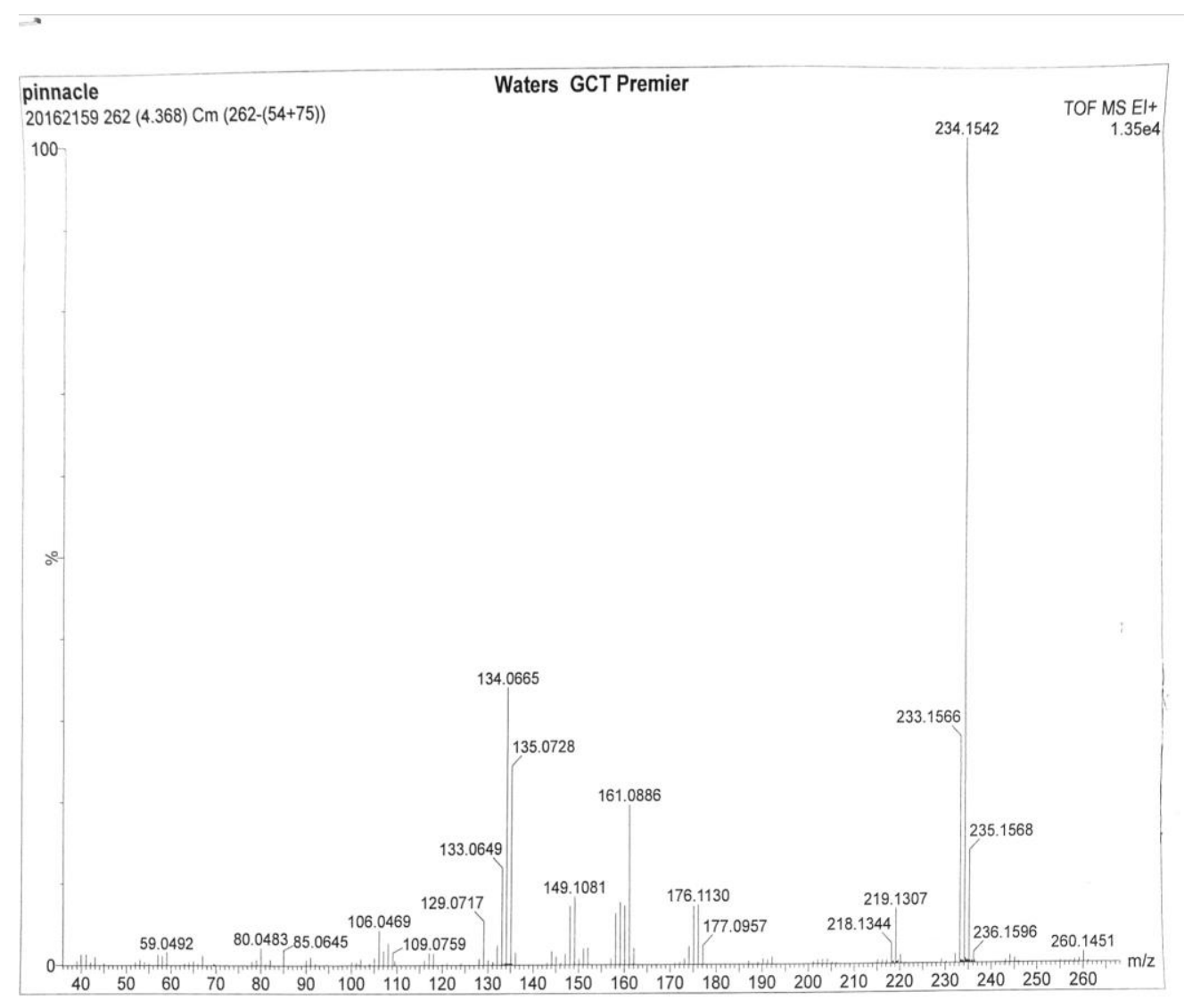

Figure S4. EI-MS of the synthesized DAPBAP molecules. $\mathrm{m} / \mathrm{z}$ calcd for $\mathrm{C}_{12} \mathrm{H}_{19} \mathrm{BN}_{2} \mathrm{O}_{2}:$ 234.1540; found: 234.1542.
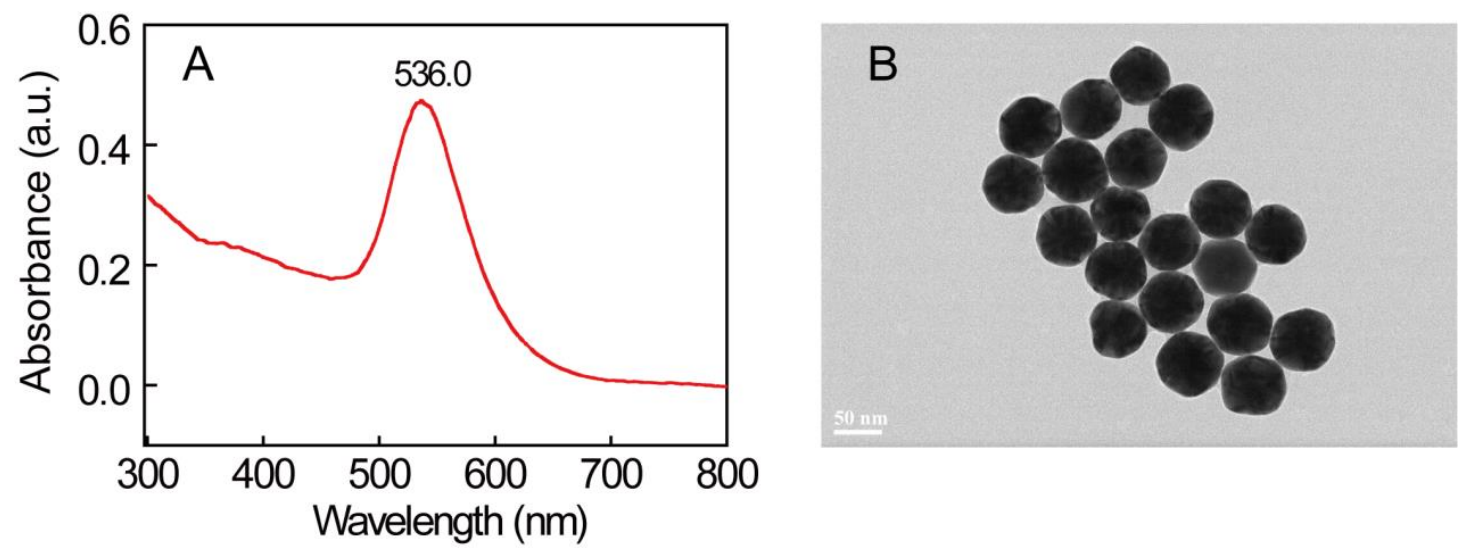

Figure S5. (A) UV-vis spectrum and (B) typical transmission electron microscopy image of AuNP/DAPBAP nanosensor. The scale bar represents 50 nm. 


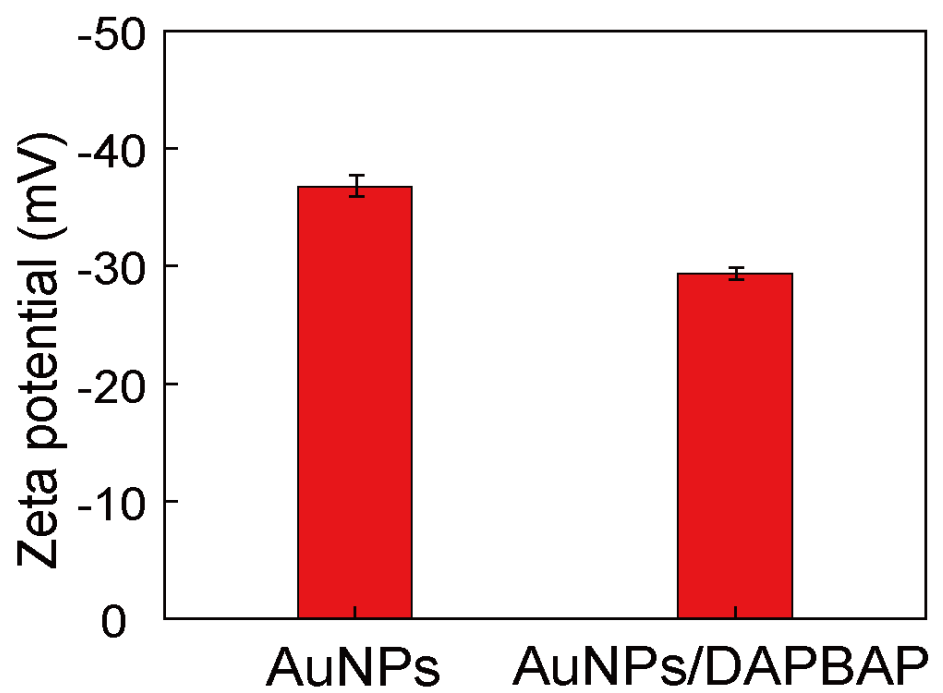

Figure S6. Zeta potentials of AuNPs and AuNP/ DAPBAP.
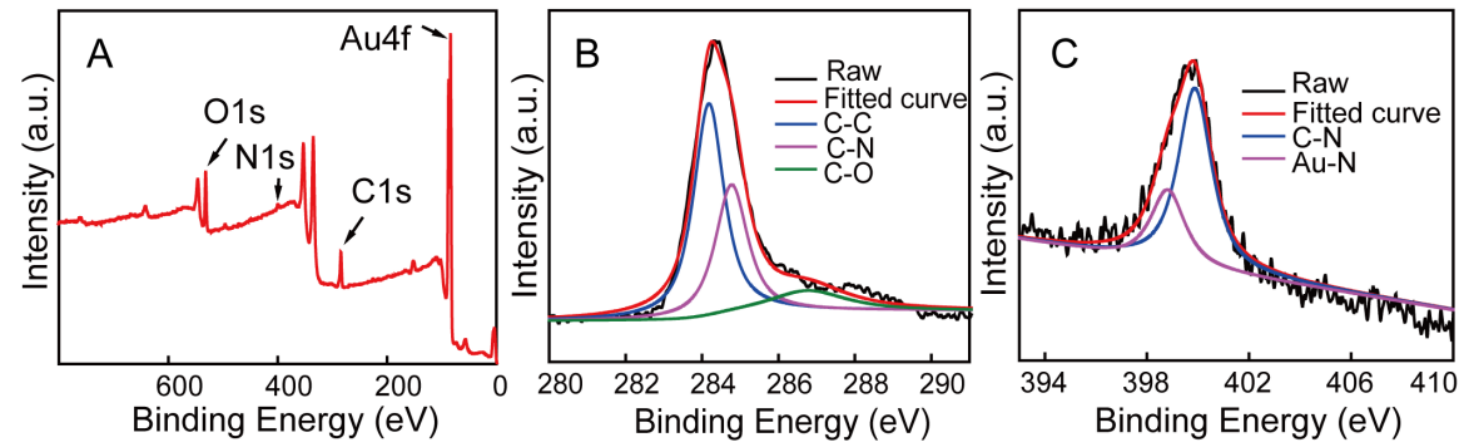

Figure S7. (A) XPS spectra of AuNP/DAPBAP; (B) C1s and (C) N1s of AuNP/DAPBAP.
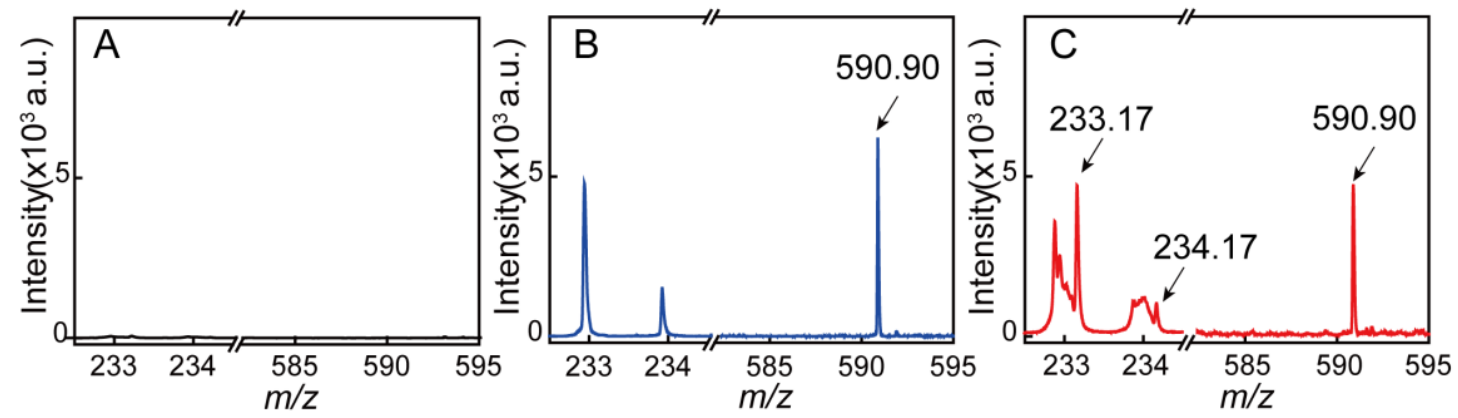

Figure S8. (A) TOF-SIMS of Si; (B) TOF-SIMS of bare AuNPs; (C) TOF-SIMS of AuNP/DAPBAP. $[\mathrm{M}]^{-}=234.17,[\mathrm{M}-\mathrm{H}]^{-}=233.17,\left[\mathrm{Au}_{3}\right]^{-}=590.90$. Negative ion mass spectra and images were recorded using a TOF-SIMS V spectrometer equipped with a 
$30 \mathrm{keV} \mathrm{Bi}_{3}{ }^{+}$primary ion source. Pulsed target current was set at $1.0 \mathrm{pA}$. Analysis area was $100 \mu \mathrm{m} \times 100 \mu \mathrm{m}$ with $128 \times 128$ pixels. 50 scans were recorded for each measurement. Cycle time was $100 \mu \mathrm{s}$.

Table S1 The deviation and assignment of the measured TOF-SIMS peaks.

\begin{tabular}{cccc}
\hline Measured m/z & Deviation/ppm & Assignment & Ion sprcies \\
\hline 233.17 & 83.8 & $\mathrm{C}_{12} \mathrm{H}_{18} \mathrm{BN}_{2} \mathrm{O}_{2}{ }^{-}$ & {$[\mathrm{M}-\mathrm{H}]^{-}$} \\
234.17 & 67.3 & $\mathrm{C}_{12} \mathrm{H}_{19} \mathrm{BN}_{2} \mathrm{O}_{2}^{-}$ & {$[\mathrm{M}]^{-}$} \\
590.90 & -1.6 & $\mathrm{Au}_{3}^{-}$ & \\
\hline
\end{tabular}

Table S2. Theoretical Raman peaks of the products of DAPBAP after reaction with $\mathrm{NO}$ and $\mathrm{ONOO}^{-}$(compound $\boldsymbol{b}$ and $\boldsymbol{c}$ in the Figure 1), and the corresponding band assignments.

\section{Compound $b$ and $c$}

\begin{tabular}{ccc}
\hline Theoretical $\left(\mathbf{c m}^{-\mathbf{1}}\right)$ & Experimental $\left(\mathbf{c m}^{-\mathbf{1}}\right)$ & Assignment \\
\hline 537 & 538 & $\rho \mathrm{C}-\mathrm{O}, v \mathrm{C}-\mathrm{N}$ \\
586 & 584 & $\delta \mathrm{CCC}$ ring, $\rho \mathrm{CCC}$ ring \\
791 & 786 & $v \mathrm{NCCN}, v \mathrm{CCC}$ ring \\
\hline
\end{tabular}

$v$, stretching vibration; $\delta$, scissoring vibration; $\rho$, rocking vibration 

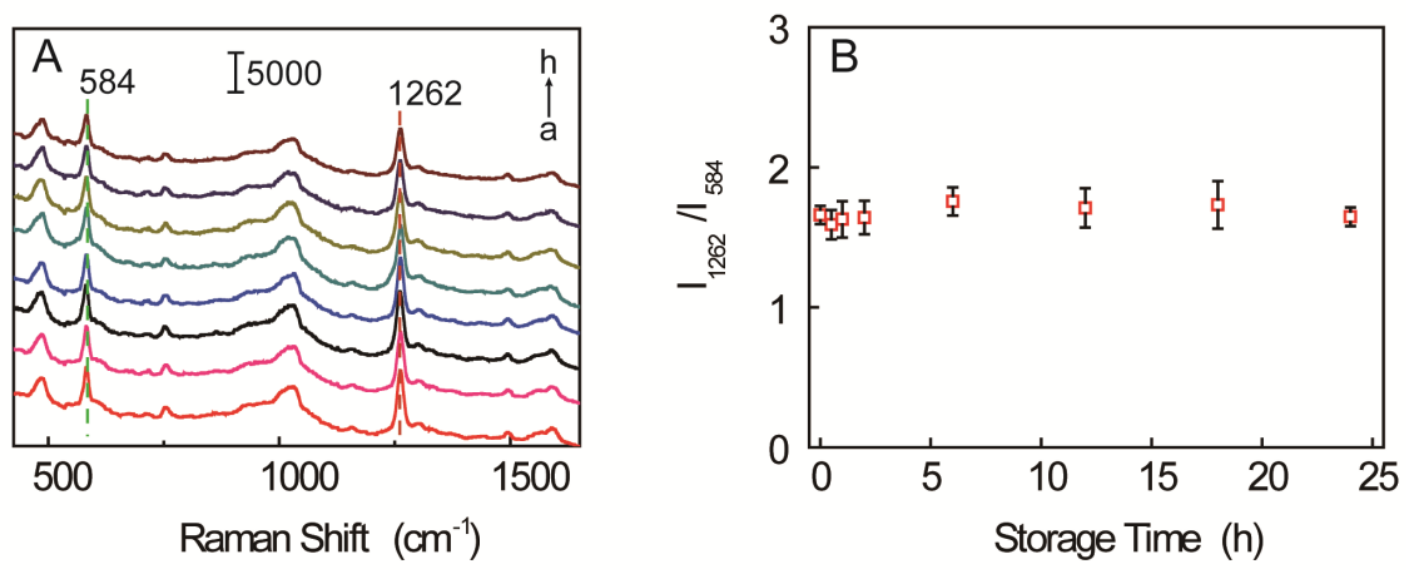

Figure S9. (A) SERS spectra of the AuNP/DAPBAP nanosensor after storage in PBS (20 mM, pH=7.4) under ambient condition for different time $(\mathrm{a}-\mathrm{h})$ : $1 \mathrm{~min}$, 30min, 1h, 2h, 6h, 12h, 18h, and 24h. (B) Ratiometric peak intensities of $\mathrm{I}_{1262} / \mathrm{I}_{584}$ versus storage time. Each data point represents the average value calculated from three replicate SERS spectra. The error bars indicate the standard deviations of the repeated measurements.
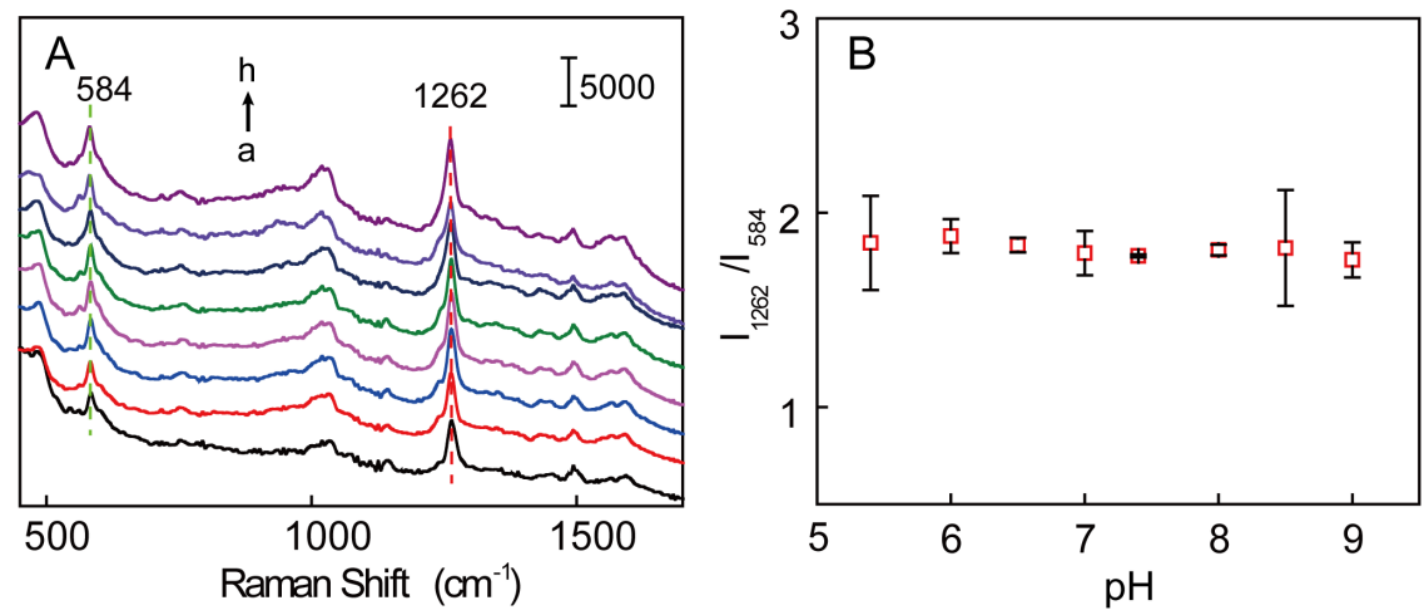

Figure S10. (A) SERS spectra of the AuNP/DAPBAP nanosensor in PBS (20 $\mathrm{mM}, \mathrm{pH}=7.4)$ with different $\mathrm{pH}(\mathrm{a}-\mathrm{h}): 5.4,6.0,6.5,7.0,7.4,8.0,8.5$, and 9.0. (B) Ratiometric peak intensities of $\mathrm{I}_{1262} / \mathrm{I}_{584}$ versus $\mathrm{pH}$ values. Each data point 
represents the average value calculated from three replicate SERS spectra. The error bars indicate the standard deviations of the repeated measurements.

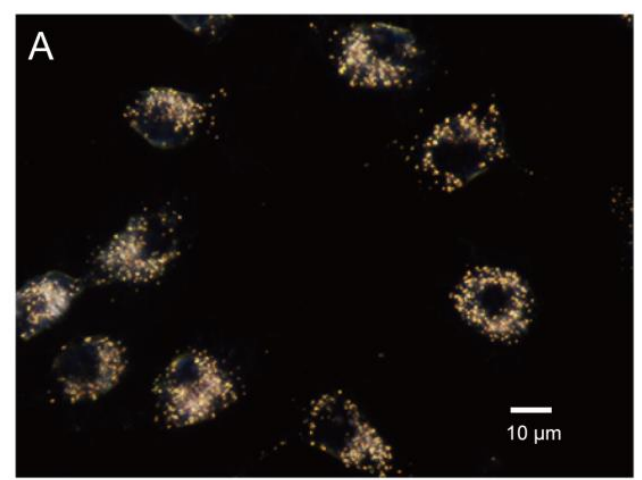

Dark-field image

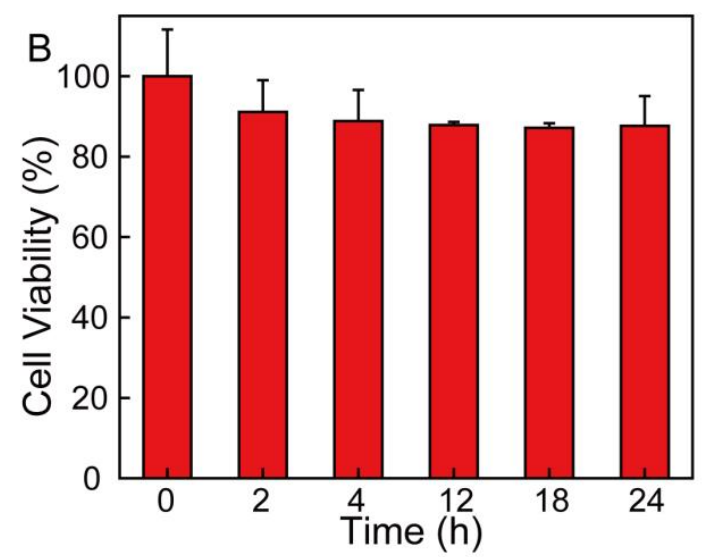

Figure S11. (A) Dark-field microscopy image of Raw264.7 macrophages incubated with AuNP/DAPBAP nanosensor for 2 h. (B) Cell viability after incubation with the fabricated AuNP/DAPBAP nanosensor for different time $(0 \mathrm{~h}, 2 \mathrm{~h}, 4 \mathrm{~h}, 12 \mathrm{~h}, 18 \mathrm{~h}$, and $24 \mathrm{~h})$.
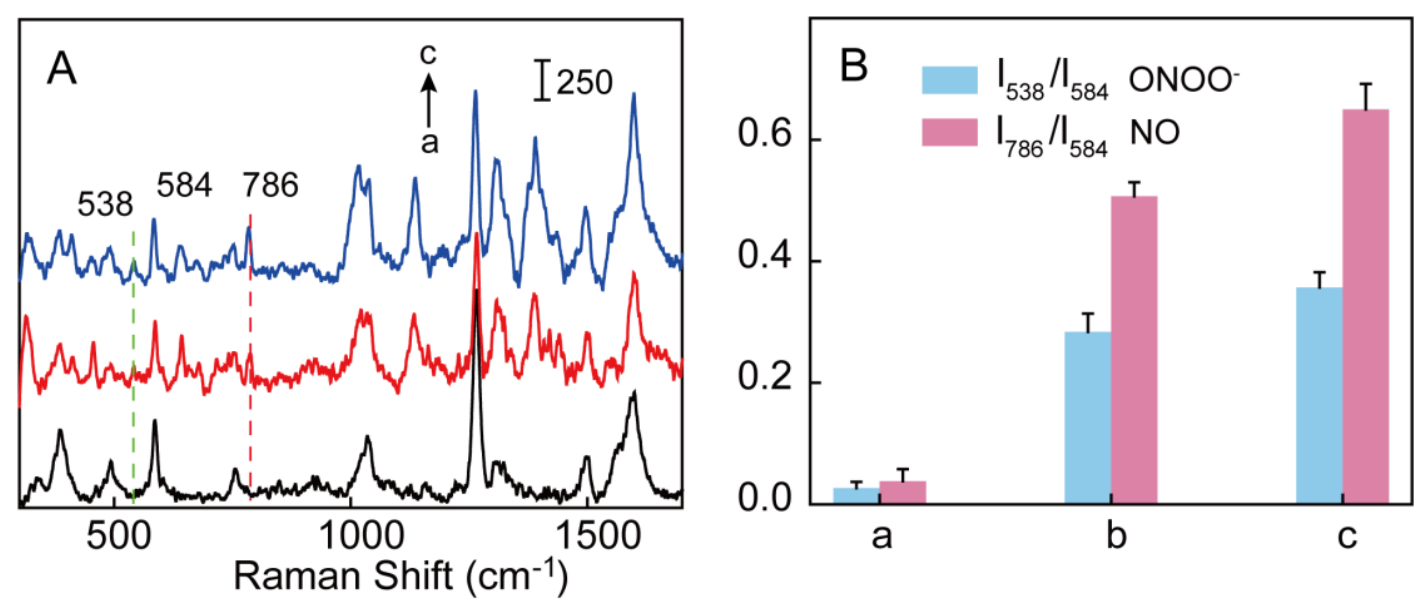

Figure S12. (A) No stimulation (a); $\mathrm{NO}=100 \mu \mathrm{M}$ and PMA for $1 \mathrm{~h}(\mathrm{~b}) ; \mathrm{NO}=200 \mu \mathrm{M}$, PMA for $1 \mathrm{~h}$ (c). (B) Ratiometric peak intensities of $\mathrm{I}_{538} / \mathrm{I}_{584}$ (blue bar) and $\mathrm{I}_{786} / \mathrm{I}_{584}$ 
(pink bar) versus the concentration of exogenous $\mathrm{NO}$ and endogenous $\mathrm{ONOO}^{-}$based on the spectra in (A)

\section{References}

1. Gaussian 09, Revision D.01, Frisch, M. J.; Trucks, G. W.; Schlegel, H. B.; Scuseria, G. E.; Robb, M. A.; Cheeseman, J. R.; Scalmani, G.; Barone, V.; Mennucci, B.; Petersson, G. A.; Nakatsuji, H.; Caricato, M.; Li, X.; Hratchian, H. P.; Izmaylov, A. F.; Bloino, J.; Zheng, G.; Sonnenberg, J. L.; Hada, M.; Ehara, M.; Toyota, K.; Fukuda, R.; Hasegawa, J.; Ishida, M.; Nakajima, T.; Honda, Y.; Kitao, O.; Nakai, H.; Vreven, T.; Montgomery, J. A., Jr.; Peralta, J. E.; Ogliaro, F.; Bearpark, M.; Heyd, J. J.; Brothers, E.; Kudin, K. N.; Staroverov, V. N.; Kobayashi, R.; Normand, J.; Raghavachari, K.; Rendell, A.; Burant, J. C.; Iyengar, S. S.; Tomasi, J.; Cossi, M.; Rega, N.; Millam, J. M.; Klene, M.; Knox, J. E.; Cross, J. B.; Bakken, V.; Adamo, C.; Jaramillo, J.; Gomperts, R.; Stratmann, R. E.; Yazyev, O.; Austin, A. J.; Cammi, R.; Pomelli, C.; Ochterski, J. W.; Martin, R. L.; Morokuma, K.; Zakrzewski, V. G.; Voth, G. A.; Salvador, P.; Dannenberg, J. J.; Dapprich, S.; Daniels, A. D.; Farkas, Ö.; Foresman, J. B.; Ortiz, J. V.; Cioslowski, J.; Fox, D. J. Gaussian, Inc., Wallingford CT, 2009.

2. Tomasi J, Mennucci B, Cances E. The IEF version of the PCM solvation method: an overview of a new method addressed to study molecular solutes at the QM ab initio level. Journal of Molecular Structure: THEOCHEM, 1999, 464(1-3): 211-226. 